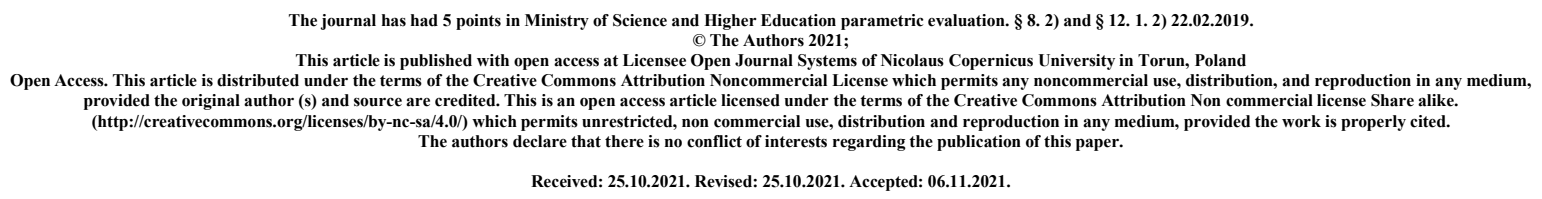

\title{
Sickness absence during the COVID-19 pandemic
}

Absencja chorobowa w dobie pandemii COVID-19

\section{Bartosz Kobuszewski}

bkobuszewski@cmkp.edu.pl

ORCID iD https://orcid.org/0000-0001-5828-1341

Department of Medical Law and Decisions, School of Public Health, Centre of Postgraduate Medical Education, Warsaw, Poland

Zakład Prawa Medycznego i Orzecznictwa Lekarskiego, Szkoła Zdrowia Publicznego, Centrum Medyczne Kształcenia Podyplomowego, Warszawa, Polska

\begin{abstract}
The aim of this research was to perform a comparative analysis of the publicly available data of the Social Insurance Institution (ZUS) on sickness absence of insured persons in Poland in 2016-2021 (before the outbreak and during the COVID-19 pandemic).

Materials and methods. The research material consisted of data from the Social Insurance Institution for the years 2016-2021 (Q1) concerning the sickness absence of the insured. Due to the publication of data in an aggregated form, quantitative analysis was performed instead of statistical analysis. The data used in the analysis included the number of insured persons, the number of people receiving sickness benefits, the number of issued medical certificates on temporary incapacity to work and the reasons for the incapacity to work.
\end{abstract}

Results and Conclusion. Since the beginning of the COVID-19 pandemic, following numbers have increased compared to 2019: the number of people receiving sickness benefit in Poland (by 10\%), the number of days of sickness absence (by $7 \%$ ) and the number of issued medical certificates of temporary incapacity for work (by 4\%). The largest increase in the number of beneficiaries, the number of days of sickness absence and the number of medical certificates was recorded in the Q4 of 2020 (respectively by $21 \%, 16 \%$ and $24 \%$ compared to Q4 of 2019). Due to COVID-19, 4.84 million days of sickness absence were used in 2020 - it was the tenth cause of absence. 
The largest changes in the number of people receiving sickness benefit and the number of days of sickness absence can be observed in Q1 and Q4, which may result from the seasonality of COVID-19 and the subsequent wave of infections. Importantly, COVID-19 is not the only factor contributing overall increase in the number of days of sickness absence in Poland - absence due to non-communicable diseases also increased during the pandemic.

Key words: COVID-19, SARS-CoV-2, pandemic, sickness absence, sick leave

\section{Wprowadzenie}

Trwająca pandemia choroby koronawirusowej COVID-19 (ang. COronaVIrus Disease 19) miała swój początek w grudniu 2019 roku w chińskim mieście Wuhan (prowincja Hubei) [1-3]. Wywoływana jest przez wirus SARS-CoV-2 (ang. Severe Acute Respiratory Syndrome Coronavirus 2), będący siódmym z grupy znanych koronawirusów wywołujących choroby u ludzi [4]. Uważa się, że pochodzi on od zwierząt takich jak nietoperze, węże czy łuskowce, a do transmisji na człowieka doszło na targu rybnym [1,3]. Do zakażenia dochodzi głównie drogą kropelkową, gdy osoba zakażona SARS-CoV-2 kicha, kaszle lub mówi [5, 6]. Objawy choroby COVID-19 obejmują gorączkę, kaszel i zmęczenie, rzadziej występują nudności i biegunka [5,7]. Ich nasilenie może być zarówno łagodne, jak i krytyczne, a część zakażeń przebiega bezobjawowo - w momencie rozpoznania choroby część pacjentów wymaga hospitalizacji i wsparcia tlenowego, a nawet leczenia na oddziale intensywnej terapii [7]. Wraz z postępem choroby może dojść do duszności, zespołu ostrej niewydolności oddechowej, posocznicy czy niewydolności wielonarządowej [7].

SARS-CoV-2 w ciągu kilku miesięcy rozprzestrzenił się w większości krajów świata wywołując światowy kryzys zdrowia publicznego. Światowa Organizacja Zdrowia (ang. World Health Organization, WHO) 30 stycznia 2020 r. uznała nowego wirusa za zagrożenie zdrowia publicznego o zasięgu międzynarodowym [8], natomiast 11 marca 2020 r. ogłosiła globalną pandemię COVID-19 [9] - w momencie ogłoszenia odnotowano 118 tys. zakażeń SARS-CoV-2 w 114 krajach świata [9]. Do tej pory na świecie odnotowano ponad $245 \mathrm{mln}$ zakażeń [10] oraz niemal 5 mln zgonów z powodu COVID-19 [11]. Pierwszy przypadek zakażenia w Polsce potwierdzono 4 marca 2020 r. [7] - od tamtej pory zakaziło się ponad 3 mln osób, z czego ponad 76 tys. zmarło [12].

Od czasu pierwszych przypadków COVID-19 pod koniec 2019 roku, SARS-CoV-2 podlega ciągłym mutacjom [13]. Obecnie amerykańskie Centers for Disease Control and Prevention (CDC) monitoruje cztery jego warianty: wariant alfa (B.1.1.7) wykryty w Wielkiej Brytanii, wariant beta (B.1.351) wykryty w Afryce Południowej, gamma (P.1) wykryty wśród Brazylijczyków oraz wariant delta wykryty w grudniu 2020 roku w Indiach. Według CDC ostatni z wymienionych wariantów rozprzestrzenia się dwukrotnie łatwiej niż pierwotny wariant alfa, przez co bardzo szybko został wykryty w 60 krajach [2]. 
CDC w ogólnych rekomendacjach kierowanych do pracowników zaleca, by w przypadku choroby (np. grypy) pozostać w domu [14]. Również WHO wśród ogólnych zaleceń dotyczących zapobiegania COVID-19 wskazuje, by w przypadku potwierdzenia zakażenia SARS-CoV-2 lub wystąpienia jego symptomów samoizolować się [15]. Pozostanie w domu w przypadku infekcji dróg oddechowych pozostaje jednym $\mathrm{z}$ najlepszych rozwiązań zapobiegających ich rozprzestrzenianiu się $[16,17]$. Stosowanie się pracowników do zaleceń jest częstsze w sytuacji, gdy mają do dyspozycji płatne dni chorobowe, w przeciwnym razie stawiani są przed trudnym wyborem między pozostaniem w domu, a pójściem do pracy chorym w celu zaspokojenia podstawowych potrzeb swoich i swojej rodziny [16].

W Polsce prawo do zasiłku chorobowego przysługuje na mocy Ustawy z dnia 25 czerwca 1999 r. o świadczeniach pieniężnych z ubezpieczenia społecznego w razie choroby i macierzyństwa (dalej: UoŚP) [18]. UoŚP wskazuje, że zasiłek chorobowy przysługuje wszystkim osobom ubezpieczonym, które stały się niezdolne do pracy z powodu choroby w czasie trwania ubezpieczenia chorobowego. Zgodnie z Ustawą z dnia 13 października 1998 r. o systemie ubezpieczeń społecznych ubezpieczeniu chorobowemu obowiązkowo podlegają m.in. pracownicy, natomiast dobrowolnie na swój wniosek mogą się ubezpieczyć m.in. osoby prowadzące pozarolniczą działalność gospodarczą, a także osoby wykonujące pracę na podstawie umowy zlecenia, jeśli podlegają obowiązkowo ubezpieczeniu emerytalnemu i ubezpieczeniu rentowemu [19]. Poza pewnymi wyjątkami, ubezpieczeni obowiązkowo nabywają prawo do otrzymania zasiłku chorobowego po 30 dniach nieprzerwanego ubezpieczenia, natomiast ubezpieczeni dobrowolnie - po 90 dniach. Świadczenie przysługuje przez „okres zasiłkowy”, tj. czas trwania niezdolności do pracy wynikającej z choroby, jednak nie dłużej niż przez 182 dni. Od 1 stycznia 2022 roku do okresu zasiłkowego będą wliczane wszystkie okresy orzeczonej niezdolności do pracy, jeżeli przerwa pomiędzy nimi (tj. zakończeniem jednego, a rozpoczęciem kolejnego okresu niezdolności do pracy) nie przekracza 60 dni, bez względu na przyczynę niezdolności. Co istotne, zasiłek chorobowy ubezpieczeni mogą otrzymać również w przypadku niemożności świadczenia pracy z powodu poddania się obowiązkowi kwarantanny, izolacji w warunkach domowych oraz izolacji, o której mowa w przepisach o zapobieganiu oraz zwalczaniu zakażeń i chorób zakaźnych u ludzi, co jest szczególnie istotne w kontekście trwającej pandemii. Zasiłek chorobowy wypłacany jest w kwocie $80 \%$ podstawy wymiaru zasiłku. Podstawowym dokumentem uprawniającym do otrzymania świadczenia jest zaświadczenie lekarskie o czasowej niezdolności do pracy, do wystawiania których zgodnie z UoŚP Zakład Ubezpieczeń Społecznych upoważnia lekarzy, po złożeniu przez nich oświadczenia o zobowiązaniu do przestrzegania zasad orzekania.

Kwestie związane z orzekaniem o czasowej niezdolności do pracy reguluje Rozporządzenie Ministra Pracy i Polityki Społecznej z dnia 10 listopada 2015 r. w sprawie trybu i sposobu orzekania o czasowej niezdolności do pracy, wystawiania zaświadczenia lekarskiego oraz trybu i sposobu sprostowania błędu w zaświadczeniu lekarskim (dalej: Rozporządzenie) [20]. O czasowej niezdolności do pracy orzeka się po przeprowadzeniu postępowania diagnostyczno-leczniczego i bierze się pod uwagę wszystkie okoliczności istotne dla oceny stanu zdrowia i upośledzenia funkcji organizmu powodujące czasową niezdolność do pracy 
ubezpieczonego, ze szczególnym uwzględnieniem rodzaju i warunków pracy. Zgodnie z Rozporządzeniem zaświadczenie lekarskie wystawiane jest na okres, w którym ubezpieczony ze względu na jego stan zdrowia powinien powstrzymać się od pracy, jednak nie dłuższy niż do dnia, w którym jest niezbędne przeprowadzenie ponownego badania stanu zdrowia ubezpieczonego.

\section{Cel}

Celem niniejszej pracy była analiza porównawcza danych Zakładu Ubezpieczeń Społecznych dotyczących absencji chorobowej (orzeczonej niezdolności do pracy w powodu choroby) ubezpieczonych w ubezpieczeniu chorobowym w Polsce w latach 2016-2021, tj. przed wybuchem pandemii COVID-19 oraz w czasie jej trwania.

\section{Material i metody}

Materiał badawczy stanowiły dane Zakładu Ubezpieczeń Społecznych za lata 2016-2021 (I. kwartał) dostępne w domenie publicznej, dotyczące absencji chorobowej ubezpieczonych, wynikającej z orzeczonej niezdolności do pracy. W związku z publikacją danych w formie zagregowanej $\mathrm{w}$ niniejszej pracy odstąpiono od przeprowadzania analizy statystycznej na rzecz analizy ilościowej. Wykorzystane w analizie dane obejmowały liczbę osób ubezpieczonych, liczbę osób pobierających zasiłek chorobowy, liczbę wystawionych zaświadczeń lekarskich o czasowej niezdolności do pracy oraz przyczyny orzeczonej niezdolności do pracy [21-23].

\section{Wyniki}

Od początku 2016 roku do końca 2019 roku obserwowano systematyczny wzrost liczby osób ubezpieczonych w ubezpieczeniu chorobowym. W pierwszym kwartale 2018 roku liczba osób podlegających ubezpieczeniu chorobowemu przekroczyła $14 \mathrm{mln}$ osób i nie spadła w kolejnych kwartałach poniżej tej liczby. W okresie epidemii COVID-19 odnotowano nieznaczny spadek liczby ubezpieczonych - między I. a III. kwartałem 2020 r. o ok. 170 tys. osób, tj. ok. - $-0,7 \%$ (Wykres 1.).

\section{Wykres 1. Liczba osób ubezpieczonych w ubezpieczeniu chorobowym w latach 2016-2021 w podziale na kwartaly [w mln]}

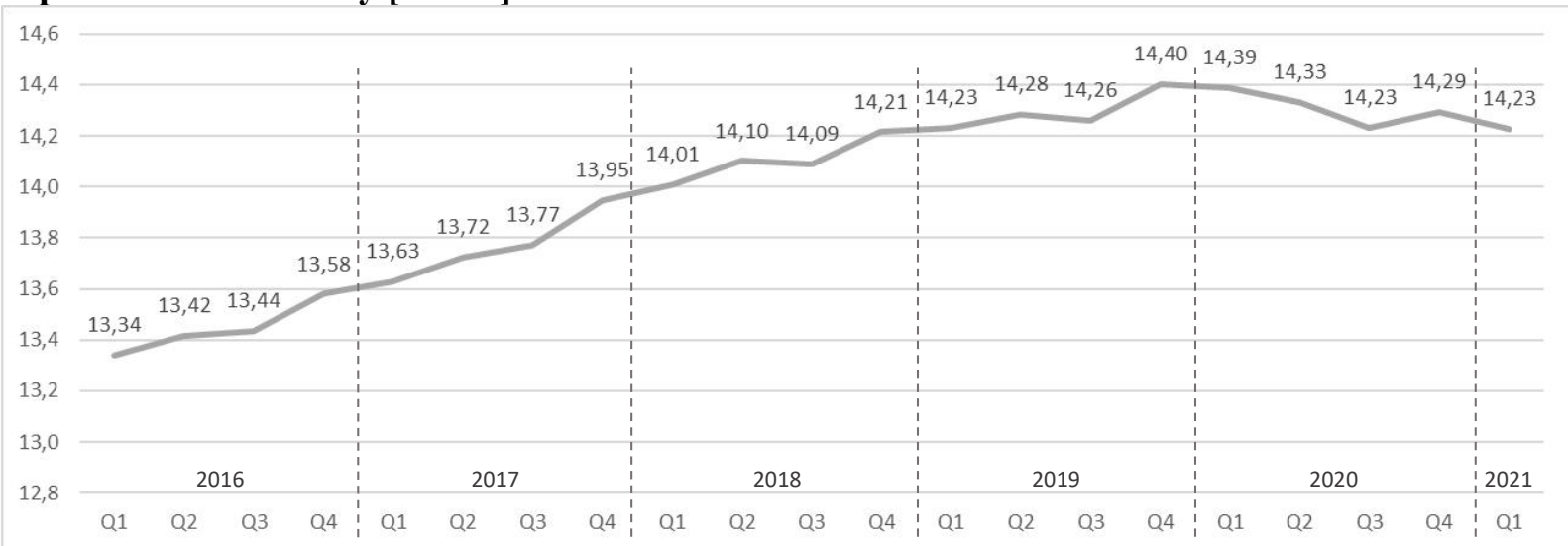

Źródło: opracowanie własne na podstawie danych ZUS 
W latach 2016-2019 liczba osób pobierających zasiłek chorobowy nie przekraczała 2,5 mln ubezpieczonych rocznie. W 2020 roku liczba korzystających z zasiłku chorobowego zwiększyła się o niemal 10\% w stosunku do roku poprzedniego i wyniosła 2,66 mln osób. Ponad połowę świadczeniobiorców stanowiły kobiety (Wykres 2.).

Wykres 2. Roczna liczba osób pobierających zasilek chorobowy w latach 2016-2020 [w mln, dynamika zmian rok do roku]

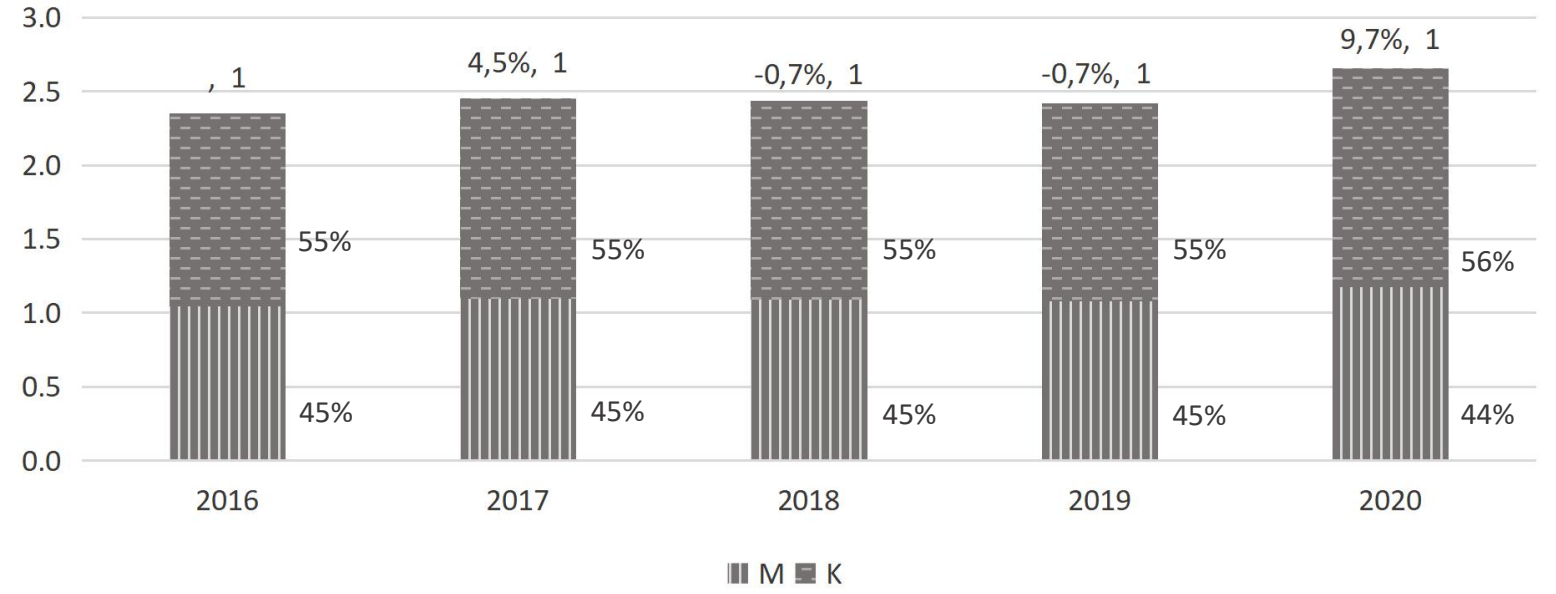

Źródło: opracowanie własne na podstawie danych ZUS

Analiza liczby osób pobierających zasiłek chorobowy w każdym kwartale wskazuje, że największą liczbę świadczeniobiorców obserwuje się w pierwszym i czwartym kwartale każdego roku - w drugim kwartale obserwuje się o ok. 9-14\% mniejszą liczbę świadczeniobiorców względem kwartału pierwszego, natomiast w czwartym kwartale obserwuje się o ok. 12-13\% większą liczbę świadczeniobiorców względem kwartału trzeciego. Kwartalna liczba pobierających zasiłek chorobowy między 2016 a 2019 rokiem nie przekraczała 1,1 mln osób. Zmianę w tym zakresie zaobserwowano w roku 2020 - w drugim kwartale, tj. wraz z początkiem epidemii w Polsce, liczba osób niezdolnych do pracy i pobierających zasiłek chorobowy była wyższa o ok. 5\% względem pierwszego kwartału i wyniosła ponad $1 \mathrm{mln}$ osób. Największy wzrost zaobserwowano w czwartym kwartale, kiedy liczba świadczeniobiorców wzrosła o ponad $28 \%$ względem poprzedniego kwartału (do ponad 1,27 mln osób), z kolei największą liczbę osób niezdolnych do pracy raportowano w pierwszym kwartale 2021 roku - 1,34 mln osób (wykres 3.). 
Wykres 2. Liczba osób pobierających zasilek chorobowy w latach 2016-2021 w podziale na kwartały [w mIn, dynamika zmian kwartal do kwartału]

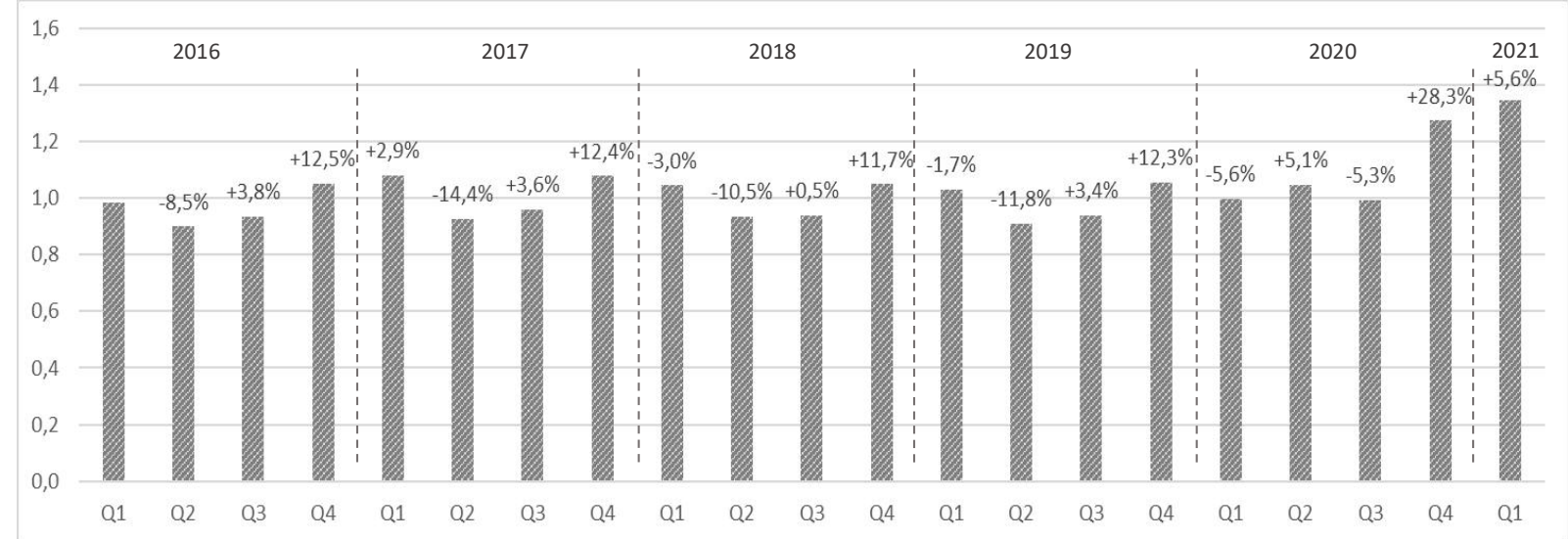

Źródło: opracowanie własne na podstawie danych ZUS

Liczba dni absencji chorobowej wynosiła w latach 2016-2019 kolejno $239 \mathrm{mln}, 246 \mathrm{mln}, 244$ mln i $239 \mathrm{mln}$ dni. Największą liczbę dni absencji, podobnie jak największą liczbę osób pobierających zasiłek chorobowy, odnotowywano w pierwszych i czwartych kwartałach. W 2020 roku liczba dni absencji chorobowej wzrosła o ponad 7\% względem roku 2019 i wyniosła $256 \mathrm{mln}$ dni (Wykres 4). Na jednego ubezpieczonego pobierającego zasiłek chorobowy przypada średnio ok. 100 dni absencji chorobowej (96 dni w 2020 roku).

\section{Wykres 4. Liczba dni absencji chorobowej osób ubezpieczonych w latach 2016-2021 [w mln]}

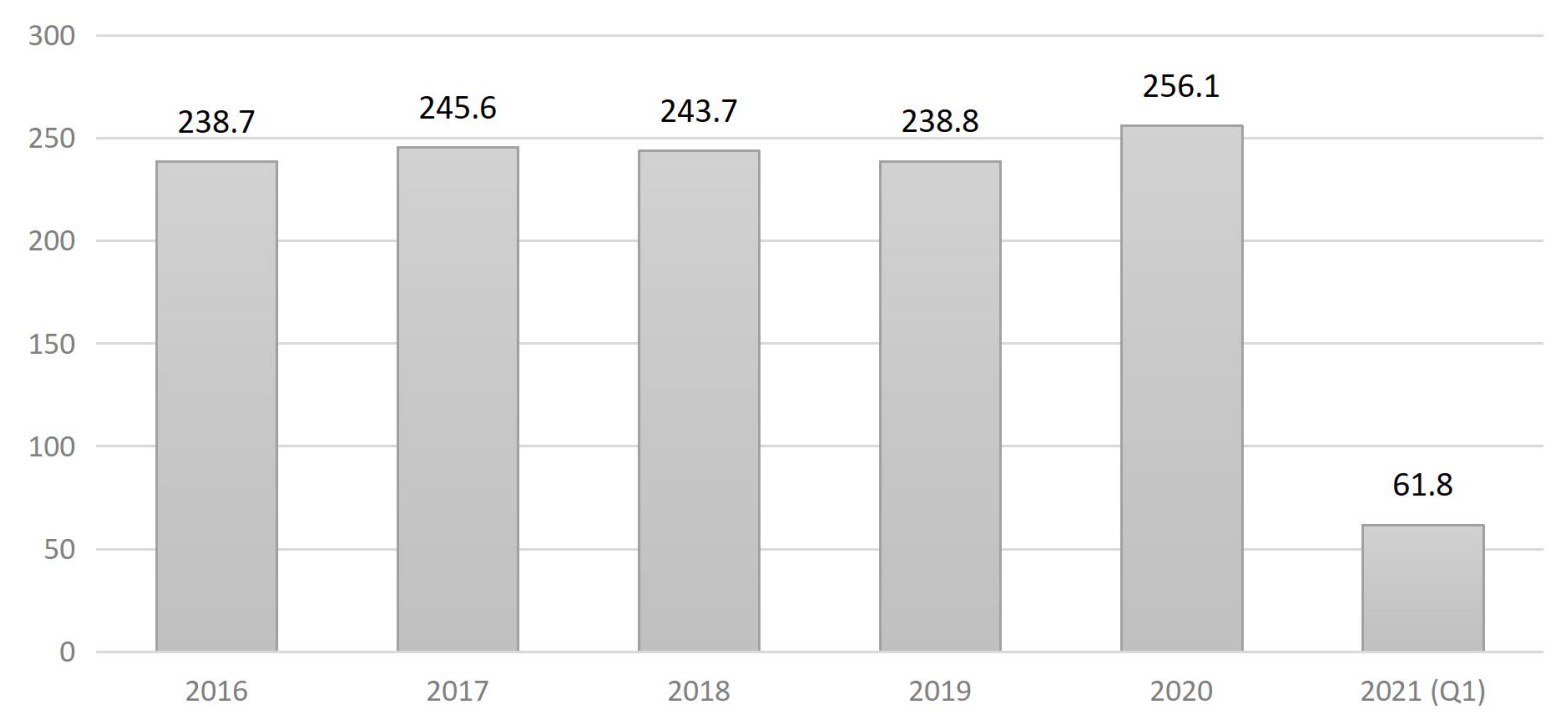

Źródło: opracowanie własne na podstawie danych ZUS

Największą liczbę dni absencji chorobowej odnotowano w I. i w IV. kwartale 2020 roku wyniosła kolejno niemal $72 \mathrm{mln}$ i ponad $70 \mathrm{mln}$ dni (tj. o ok. 11\% i 16\% więcej w stosunku do roku poprzedniego). Z kolei w pierwszym kwartale $2021 \mathrm{r}$. liczba dni absencji chorobowej była najniższa od 2016 roku i o ok. 14\% niższa niż w roku 2020 (Wykres 5.), przy równocześnie najwyższej liczbie osób pobierających zasiłek chorobowy (Wykres 2.). 
Wykres 5. Liczba dni absencji chorobowej osób ubezpieczonych w latach 2016-2021 w podziale na kwartały [w mIn, dynamika zmian rok do roku]

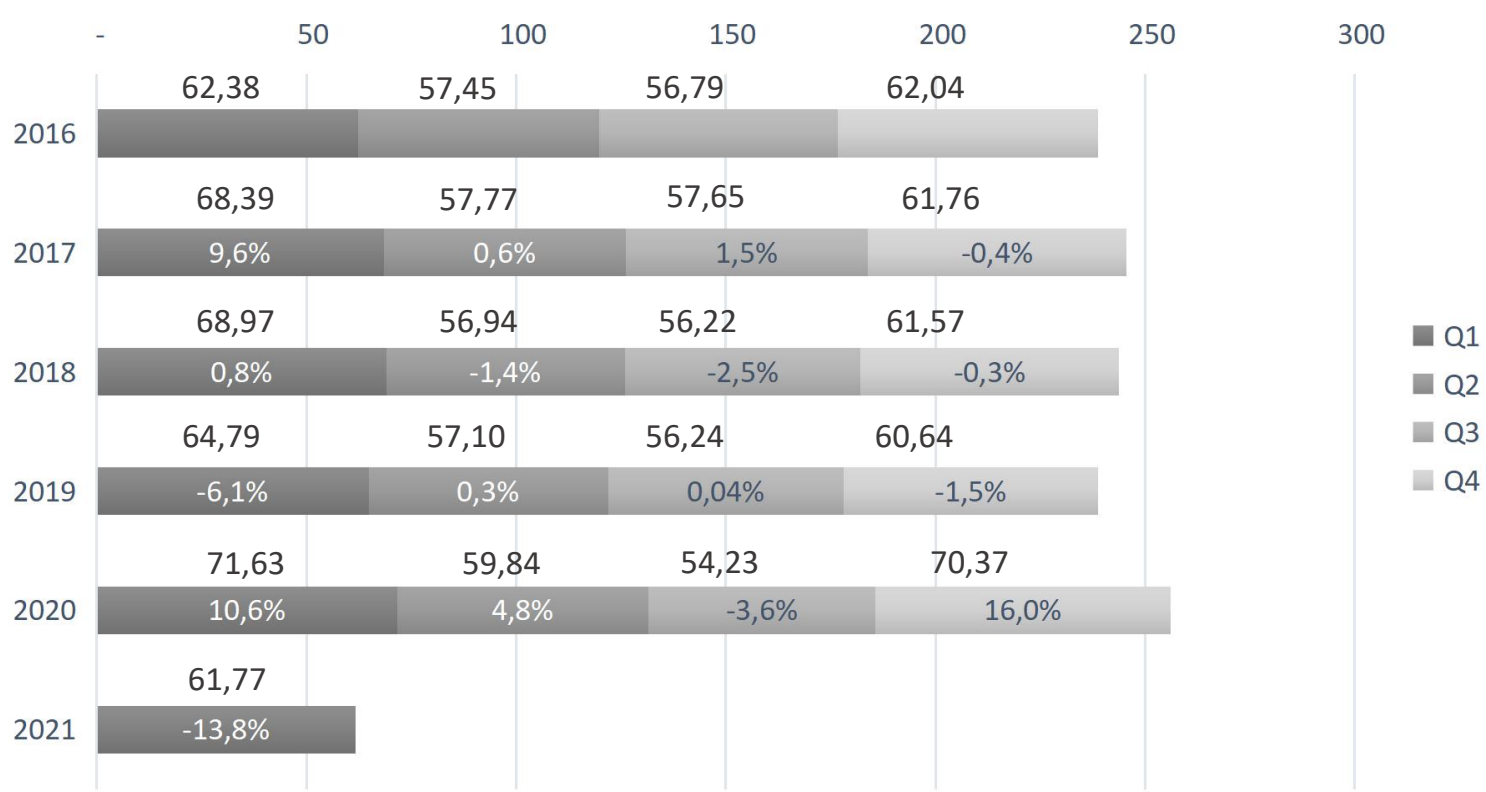

Źródło: opracowanie własne na podstawie danych ZUS

Liczba wystawianych zaświadczeń lekarskich o czasowej niezdolności do pracy wyniosła w 2020 roku 20,73 mln i była wyższa o ok. 4\% względem 2019 roku. Po raz pierwszy w analizowanym okresie roczna liczba wystawionych zaświadczeń przekroczyła $20 \mathrm{mln}$. Najwięcej zaświadczeń lekarze wystawili w I. i IV. kwartale 2020 r. - kolejno 6,24 mln i $6,41 \mathrm{mln}$, tj. o ok. 8\% i 24\% więcej niż w analogicznych okresach roku 2019 (Wykres 6). Jedno zaświadczenie lekarskie obejmuje średnio ok. 12 dni (12,4 dnia w 2020 roku), przy czym w II. kwartale 2020 roku było to 15 dni.

Wykres 6. Liczba wystawionych zaświadczeń lekarskich o czasowej niezdolności do pracy w latach 2016-2021 w podziale na kwartale [w mln, dynamika zmian rok do roku]

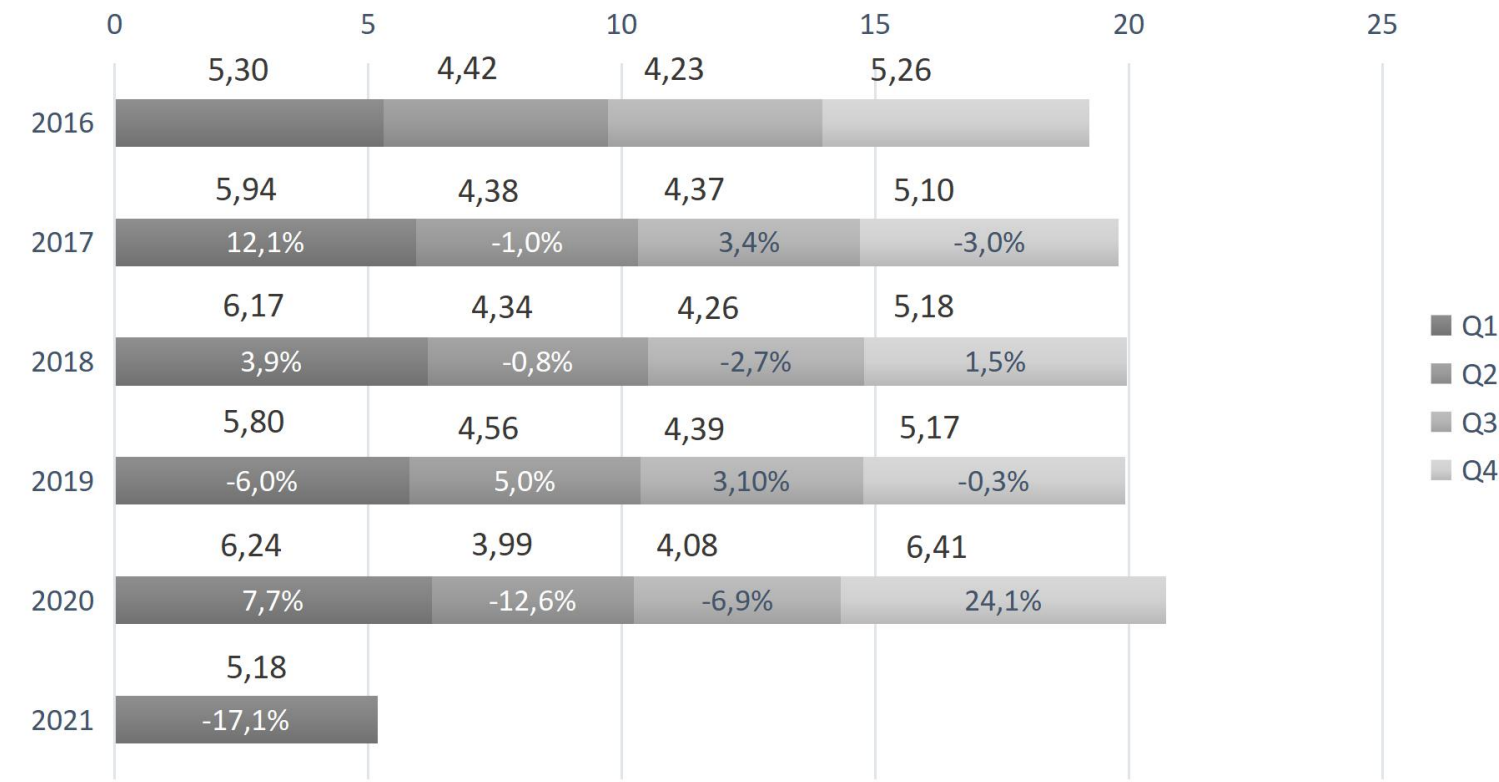

Źródło: opracowanie własne na podstawie danych ZUS 
Każdego roku pięć grup schorzeń wg klasyfikacji ICD-10 odpowiada za ok. ${ }^{2 / 3}$ dni absencji chorobowej ogółem. W latach 2016-2021 w pierwszej piątce znajdowały się: urazy, zatrucia i inne określone skutki działania czynników zewnętrznych (grupa S), choroby układu oddechowego (grupa J), choroby układu mięśniowo-szkieletowego i tkanki łącznej (grupa M) oraz ciąża, poród i okres połogu (grupa O). W roku 2016 i 2017 na piątym miejscu znajdowały się choroby układu nerwowego (grupa G), które w 2018 zastąpiły zaburzenia psychiczne i zaburzenia zachowania (grupa F). Od lat główną przyczyną absencji chorobowej pozostają rozpoznania z grupy $\mathrm{O}$, które odpowiadają każdego roku za ponad $45 \mathrm{mln}$ dni absencji chorobowej. Na drugim miejscu natomiast znajdują się rozpoznania $\mathrm{z}$ grupy $\mathrm{M}-\mathrm{w}$ 2020 roku z powodu chorób układu mięśniowo-szkieletowego ubezpieczeni przebywali na zwolnieniach ponad $41 \mathrm{mln}$ dni, co stanowi wzrost o ok. $10 \%$ względem roku 2019 . W zakresie kolejnych najczęstszych przyczyn niezdolności do pracy w 2020 roku zaszły zmiany w stosunku do 2019 roku: wzrósł udział rozpoznań z grupy J oraz $\mathrm{F}$ (kolejno wzrost o ok. $20 \%$ do $35 \mathrm{mln}$ dni i o ok. $37 \%$ do $28 \mathrm{mln}$ dni), spadła natomiast liczba dni absencji powodowanej urazami, zatruciami i innymi czynnikami zewnętrznymi (Wykres 7.).

Wykres 7. Liczba dni absencji chorobowej w latach 2016-2021 - pięć najczęstszych przyczyn wg grup schorzeń zgodnie z klasyfikacją ICD-10 [w mln]

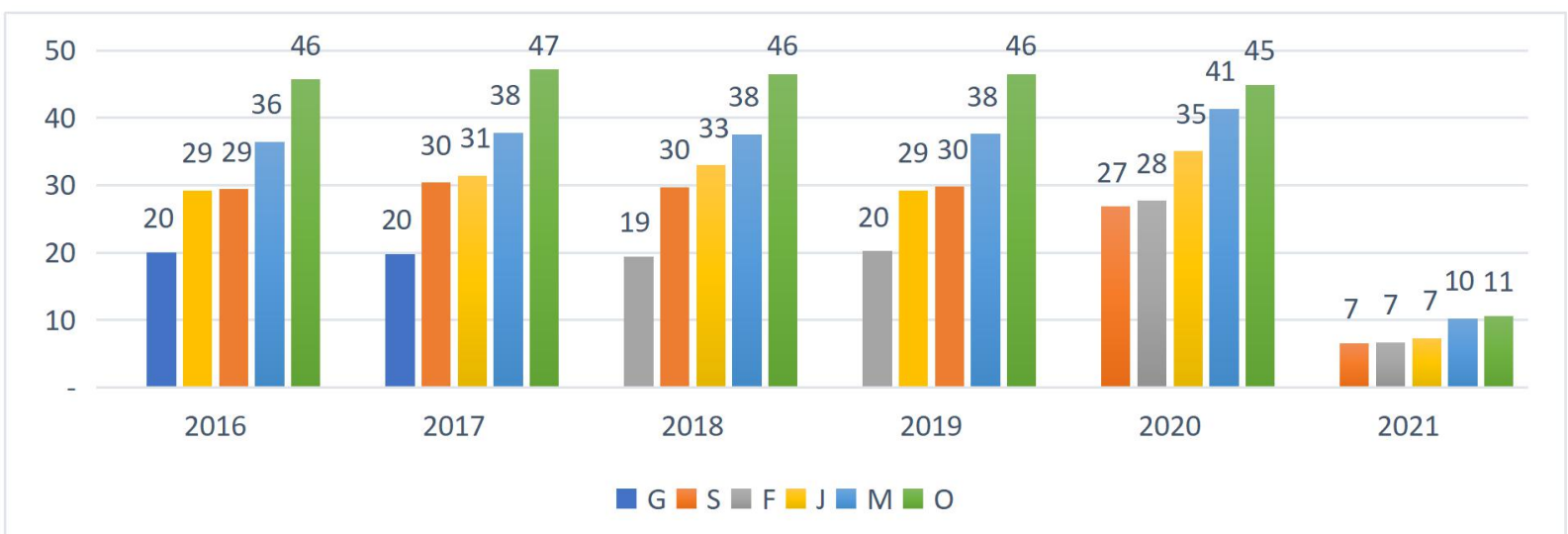

Źródło: opracowanie własne na podstawie danych ZUS

Biorąc pod uwagę konkretne rozpoznania, stanowiące przyczynę niezdolności do pracy (kategorie trzyznakowe wg ICD-10) należy wskazać, że pierwszych dziesięć rozpoznań odpowiada za ok. 40\% wszystkich dni absencji chorobowej (44\% w 2020 roku). W latach 2016-2019 w pierwszej dziesiątce najczęstszych powodów niezdolności do pracy niezmiennie znajdowały się:

- opieka położnicza z powodu stanów związanych głównie z ciążą (O26);

- zaburzenia korzeni i splotów nerwowych (G54);

- ostre zakażenie górnych dróg oddechowych o umiejscowieniu mnogim lub nieokreślonym (J06);

- bóle grzbietu (M54);

- reakcja na ciężki stres i zaburzenia adaptacyjne (F43);

- inne choroby krążka międzykręgowego (M51);

- ostre zapalenie nosa i gardła [przeziębienie] (J00); 
- spondyloza (M47);

- epizod depresyjny (F32);

- krwawienie we wczesnej ciąży $(\mathrm{O} 20)$.

W 2020 roku w pierwszej dziesiątce znalazły się także rozpoznania: inne zaburzenia lękowe (F41) oraz COVID-19 (U07), zamiast rozpoznań M47 oraz O20. Największy wzrost liczby dni absencji chorobowej odnotowano dla rozpoznań J00 ( $\uparrow$ o ok. 81\% względem roku 2019, do $8,25 \mathrm{mln}$ dni), F41 ( $\uparrow$ o ok. 62\% względem roku 2019, do 4,91 mln dni) oraz F43 ( $\uparrow$ o ok. 49\% względem roku 2019, do 9,77 mln dni). COVID-19 był odpowiedzialny za 4,84 mln dni absencji chorobowej w 2020 roku oraz za 1,58 mln dni w pierwszym kwartale 2021 roku (Wykres 8.).

Zaświadczenia lekarskie wskazujące na niezdolność do pracy $\mathrm{z}$ powodu wymienionych powyżej chorób obejmowały w 2020 roku średnio od 5 dni (J00) do 24 dni (O26). W przypadku COVID-19 średnia długość zaświadczenia lekarskiego wyniosła 8 dni. 
Wykres 8. Liczba dni absencji chorobowej w latach 2016-2021 - dziesięć najczęstszych przyczyn wg rozpoznań zgodnie z klasyfikacją ICD-10 [w mIn, dynamika zmian rok do roku]

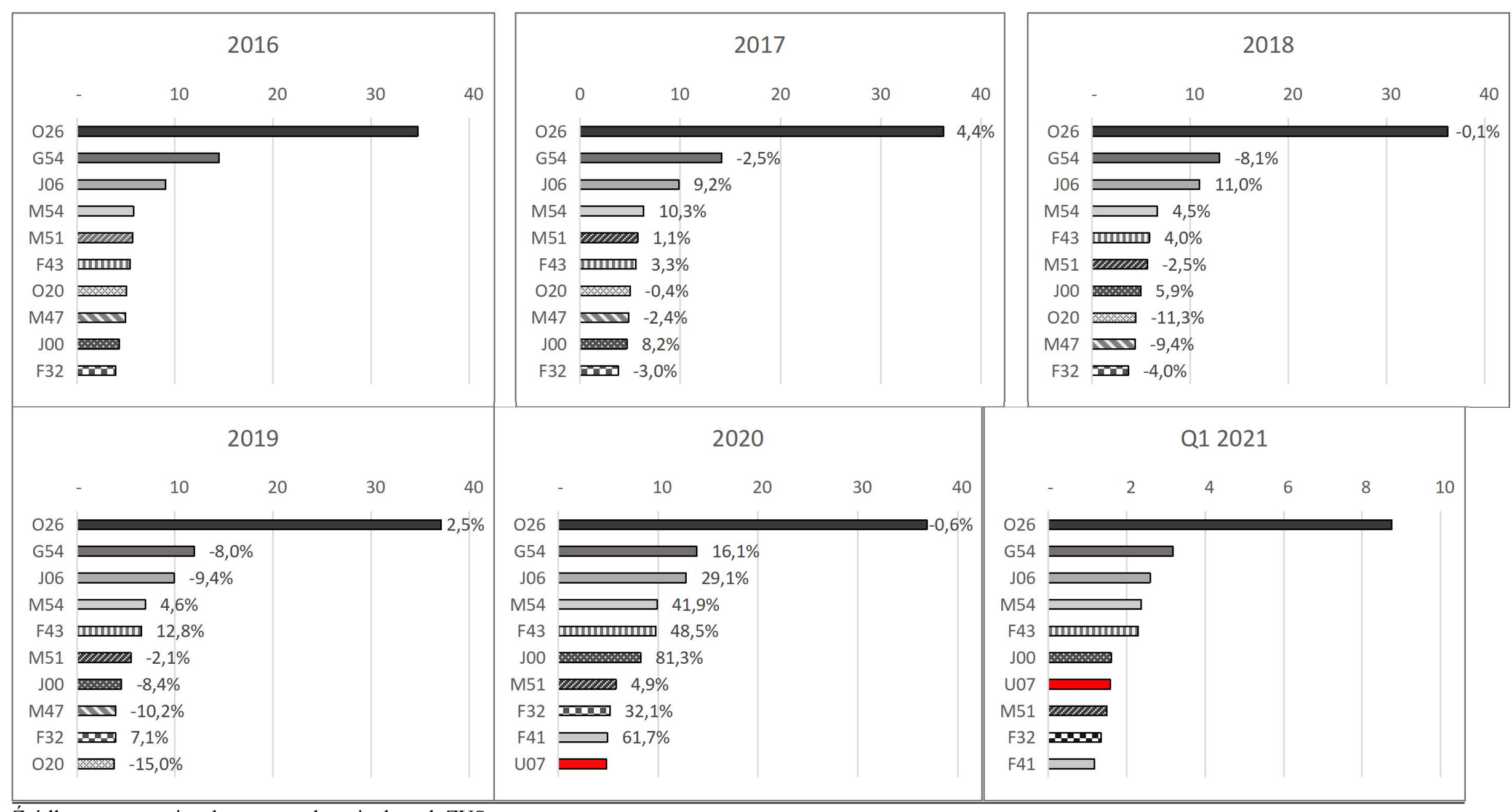

Źródło: opracowanie własne na podstawie danych ZUS 


\section{Dyskusja i wnioski}

W literaturze [16] wskazuje się na istotność dostępu do płatnych zwolnień chorobowych, które zmniejszają prawdopodobieństwo udania się do pracy chorym [24-26] - pracownicy niemający możliwości skorzystania $\mathrm{z}$ takiego zwolnienia 1,5 razy częściej są skłonni do udania się do pracy mimo choroby i mniej skłonni do skorzystania $\mathrm{z}$ porady lekarskiej $\mathrm{w}$ czasie choroby [27]. Badania wskazują także, że funkcjonowanie płatnych zwolnień lekarskich wpływa na ograniczenie rozprzestrzeniania się chorób układu oddechowego [28, 29].

W Polsce wszystkie osoby pracujące na podstawie umowy o pracę obowiązkowo podlegają ubezpieczeniu chorobowemu, dzięki czemu w razie niezdolności do pracy wynikającej $\mathrm{z}$ choroby mogą skorzystać $\mathrm{z}$ zasiłku chorobowego. Zgodnie $\mathrm{z}$ danymi publikowanymi przez Zakład Ubezpieczeń Społecznych od początku epidemii COVID-19, w Polsce wzrosła liczba osób pobierających zasiłek chorobowy ( $\uparrow$ o ok. 10\% względem roku 2019) oraz liczba dni absencji chorobowej ( $\uparrow$ o ok. 7\% względem roku 2019) i liczba wystawianych zaświadczeń lekarskich o czasowej niezdolności do pracy ( $\uparrow$ o ok. 4\% względem roku 2019). Największy wzrost zarówno liczby świadczeniobiorców, jak i liczby dni absencji chorobowej oraz liczby zaświadczeń lekarskich odnotowano natomiast w IV kwartale 2020 roku ( $\uparrow$ kolejno o ok. $21 \%$, ok. $16 \%$ i ok. 24\% względem roku 2019).

W czasie epidemii COVID-19 wzrosła liczba dni niezdolności do pracy spowodowana chorobami układu mięśniowo-szkieletowego i tkanki łącznej ( $\uparrow$ o ok. 10\% względem roku 2019), chorobami układu oddechowego ( $\uparrow$ o ok. 20\%) oraz zaburzeniami psychicznymi i zaburzeniami zachowania ( $\uparrow$ o ok. 37\%). Wśród dziecięciu rozpoznań odpowiadających za największą liczbę dni absencji chorobowej (44\% liczby dni ogółem) największy wzrost liczby dni dotyczył ostrego zapalenia nosa i gardła ( $\uparrow$ o ok. 81\% względem roku 2019), innych zaburzeń lękowych ( $\uparrow$ o ok. 62\%) oraz reakcji na ciężki stres i zaburzeń adaptacyjnych ( $\uparrow$ o ok. 49\%). Z powodu COVID-19 w 2020 wykorzystano 4,84 mln dni absencji chorobowej (dziesiąta przyczyna absencji) oraz za 1,58 mln dni w pierwszym kwartale 2021 roku (siódma przyczyna absencji). Zaświadczenie lekarskie o czasowej niezdolności do pracy z powodu COVID-19 obejmowało średnio 8 dni.

Dane Eurostatu, dotyczące absencji chorobowej w całej Unii Europejskiej [30] wskazują na podobną tendencję, jak obserwowana w Polsce. W I. i II. kwartale 2020 roku odnotowano zdecydowanie wyższą absencję osób w wieku 20-64 lata - kolejno: 23,5 mln osób i 35,3 mln osób w porównaniu z 18,1 mln osób w IV kwartale 2019 roku (tj. o ok. 30\% i ok. 95\% więcej niż w IV. kwartale 2019 r.). W III. kwartale liczba osób była zbliżona do tej z IV. kwartału 2019 r. (17,9 mln osób), by ponownie wzrosnąć w IV. kwartale do 22,3 mln osób.

Największe zmiany w liczbie osób korzystających z zasiłku chorobowego oraz liczbie dni absencji chorobowej można zaobserwować w I. i IV. kwartale, co może wynikać z sezonowości zachorowań na COVID-19 i kolejnych fal zakażeń. Co istotne, COVID-19 nie odpowiada za ogólny wzrost liczby dni absencji chorobowej w Polsce, bowiem w okresie pandemii wzrosła również absencja $\mathrm{z}$ powodu chorób niezakaźnych. Określenie relacji 
między zarówno ogólnym wzrostem absencji chorobowej, jak i wzrostem z powodu określonych jednostek chorobowych, a pandemią COVID-19 wymaga dalszych badań.

\section{Bibliografia}

[1] Hui D. et al. The continuing 2019-nCoV epidemic threat of novel coronaviruses to global health-The latest 2019 novel coronavirus outbreak in Wuhan, China. International journal of infectious diseases, 2020, 91: 264-266. https://doi.org/10.1016/j.ijid.2020.01.009

[2] Shiehzadegan S. et al. Analysis of the Delta Variant B. 1.617. 2 COVID-19. Clinics and Practice, 2021, 11.4: 778-784. https://doi.org/10.3390/clinpract11040093

[3] Ji W. et al. Cross-species transmission of the newly identified coronavirus 2019-nCoV. Journal of medical virology, 2020, 92.4: 433-440. https://doi.org/10.1002/jmv.25682

[4] Zhu N. et al. A novel coronavirus from patients with pneumonia in China, 2019. New England journal of medicine, 2020. https://doi.org/10.1056/NEJMoa2001017

[5] Li J. et al. Epidemiology of COVID-19: A systematic review and meta-analysis of clinical characteristics, risk factors, and outcomes. Journal of medical virology, 2021, 93.3: 1449-1458. https://doi.org/10.1002/jmv.26424

[6] Gujski M. et al. Characteristics and Clinical Outcomes of 116,539 Patients Hospitalized with COVID-19_Poland, March-December 2020. Viruses, 2021, 13.8: 1458. https://doi.org/10.3390/v13081458

[7] Gujski M. et al. Epidemiological analysis of the first 1389 cases of COVID-19 in Poland: A preliminary report. Medical science monitor: international medical journal of experimental and clinical research, 2020, 26: e924702-1. https://doi.org/10.12659/MSM.924702

[8] Światowa Organizacja Zdrowia. Oświadczenie na posiedzeniu Komitetu ds. Dyspozycji Międzynarodowych Przepisów Zdrowotnych (2005) w sprawie wybuchu nowego koronawirusa (2019-nCoV). Genewa: WHO; 2020. https://www.who.int/news/item/3001-2020-statement-on-the-second-meeting-of-the-international-health-regulations(2005)-emergency-committee-regarding-the-outbreak-of-novel-coronavirus-(2019-ncov) [dostęp: 1.11.2021 r.]

[9] Uwagi wstępne Dyrektora Generalnego WHO na briefingu medialnym na temat COVID-19 - 11 marca 2020 r. https://www.who.int/directorgeneral/speeches/detail/who-director-general-s-opening-remarks-at-the-media-briefingon-covid-19---11-march-2020 [dostęp: 1.11.2021 r.]

[10] Coronavirus (COVID-19) Cases, Our World in Data, Statistics and Research https://ourworldindata.org/covid-cases?country= OWID_WRL [dostęp: 1.11.2021 r.]

[11] Coronavirus (COVID-19) Deaths, Our World in Data, Statistics and Research https://ourworldindata.org/covid-deaths? country= OWID_WRL [dostęp: 1.11.2021 r.] 
[12] Poland: Coronavirus Pandemic Country Profile, Our World in Data https://ourworldindata.org/coronavirus/country/poland [dostęp: 1.11.2021 r.]

[13] Boehm E. et al. Novel SARS-CoV-2 variants: the pandemics within the pandemic. Clinical Microbiology and Infection, 2021. https://doi.org/10.1016/j.cmi.2021.05.022

[14] Centers for Disease Control and Prevention, Stay Home When You Are Sick, https://www.cdc.gov/flu/business/stay-home-when-sick.htm [dostęp: 1.11.2021 r.]

[15] Światowa Organizacja Zdrowia, Advice for the public: Coronavirus disease (COVID-19) https://www.who.int/emergencies/diseases/novel-coronavirus-2019/advice-for-public [dostęp: 1.11.2021 r.]

[16] Heymann J. et al. Protecting health during COVID-19 and beyond: a global examination of paid sick leave design in 193 countries. Global public health, 2020, 15.7: 925-934. https://doi.org/10.1080/17441692.2020.1764076

[17] Barrios L.C. et al. Selecting nonpharmaceutical strategies to minimize influenza spread: the 2009 influenza A (H1N1) pandemic and beyond. Public Health Reports, 2012, 127.6: 565-571. https://doi.org/10.1177/003335491212700606

[18] Ustawa z dnia 25 czerwca 1999 r. o świadczeniach pieniężnych z ubezpieczenia społecznego w razie choroby i macierzyństwa. (Dz.U. 2021 poz. 1133 z późn. zm.) https://www.dziennikustaw.gov.pl/DU/2021/1133 [dostęp: 1.11.2021 r.]

[19] Ustawa z dnia 13 października 1998 r. o systemie ubezpieczeń społecznych. (Dz.U. 2021 poz. 423 z późn. zm.) https://www.dziennikustaw.gov.pl/DU/2021/423 [dostęp: 1.11.2021 r.]

[20] Rozporządzenie Ministra Pracy i Polityki Społecznej z dnia 10 listopada 2015 r. w sprawie trybu i sposobu orzekania o czasowej niezdolności do pracy, wystawiania zaświadczenia lekarskiego oraz trybu i sposobu sprostowania błędu w zaświadczeniu lekarskim (Dz.U. 2015 poz. 2013) https://www.dziennikustaw.gov.pl/DU/2015/2013 [dostęp: 1.11.2021 r.]

[21] Zakład Ubezpieczeń Społecznych, Portal Statystyczny ZUS: Ubezpieczenia Chorobowe https://psz.zus.pl/kategorie/ubezpieczeni/ubezpieczenia-chorobowe

[dostęp: 1.11.2021 r.]

[22] Zakład Ubezpieczeń Społecznych, Portal Statystyczny ZUS: Zasiłki https://psz.zus.pl/kategorie/zasilki [dostęp: 1.11.2021 r.]

[23] Zakład Ubezpieczeń Społecznych, Portal Statystyczny ZUS: Absencja chorobowa z tytułu choroby własnej osób ubezpieczonych w ZUS [dostęp: 1.11.2021 r.] https://psz.zus.pl/kategorie/absencja-chorobowa/absencja-chorobowa-z-tytulu-chorobywlasnej-osob-ubezpieczonych-w-zus

[24] Derigne LA. Et al. Workers without paid sick leave less likely to take time off for illness or injury compared to those with paid sick leave. Health Affairs, 2016, 35.3: 520527.; https://doi.org/10.1377/hlthaff.2015.0965

[25] Piper K. et al. Paid sick days and stay-at-home behavior for influenza. PLoS One, 2017, 12.2: e0170698. https://doi.org/10.1371/journal.pone.0170698 
[26] Schneider D. Paid sick leave in Washington state: Evidence on employee outcomes, 2016-2018. American journal of public health, 2020, 110.4: 499-504 https://doi.org/10.2105/AJPH.2019.305481

[27] Cordoba E. et al., Social determinants of influenza illness and outbreaks in the United States. North Carolina Medical Journal, 2016, 77.5: 341-345. https://doi.org/10.18043/ncm.77.5.341

[28] Kumar S. et al. The impact of workplace policies and other social factors on selfreported influenza-like illness incidence during the $2009 \mathrm{H} 1 \mathrm{N1}$ pandemic. American Journal of Public Health, 2012, 102.1: 134-140. https://doi.org/10.2105/AJPH.2011.300307

[29] Zhai Y. et al. Paid sick leave benefits, influenza vaccination, and taking sick days due to influenza-like illness among US workers. Vaccine, 2018, 36.48: 7316-7323. https://doi.org/10.1016/j.vaccine.2018.10.039

[30] Eurostat, Statistics Explained, Absences from work - quarterly statistics https://ec.europa.eu/eurostat/statistics-

explained/index.php?title=Absences from_work _-

quarterly_statistics\#Absences_from_work_sharply_increase_in_first_half_of_2020.2C _decrease_in_the 3rd quarter_then_increase_again_in the 4th_quarter [dostęp: $1.11 .2021 \mathrm{r}$. 